\title{
The Effect of Soft Skill on the Readiness of Students in Facing Employement at the Civil Engineering Study Program at Universitas Negeri Semarang
}

\author{
Aris Widodo ${ }^{1}$, Ika Yuniarsih Wiranti ${ }^{2}$ \\ \{ ariswidodo71@mail.unnes.ac.id ${ }^{1}$,ikayuniarsih.w@gmail.com ${ }^{2}$ \}
}

Department of Civil Engineering, Faculty of Engineering , Universitas Negeri Semarang ${ }^{1,2}$

\begin{abstract}
In higher education, students are required to be graduates who can bring success in developing career paths or professional workforce. Therefore, it is necessary to develop the hard skills of the students. In addition, they must also develop the soft skills of each student themselves. The purpose of this study was to determine the effect of soft skills on students' readiness in facing the employment in the Civil Engineering study program at the Universitas Negeri Semarang in 2016. This research was included in the regression research. From the descriptive analysis in this study, the level of soft skills ability of class of 2016 Civil Engineering students of the Universitas Negeri Semarang were included in the category of fair with the average score $=95.5$. The work readiness of students of the Civil Engineering study program, Universitas Negeri Semarang was included in the category of Fair with an average value of 102.7. The results of this study also showed that the correlation coefficient ( $\mathrm{r}_{\text {statistics }}$ )has a positive value, then the two variables have a direct relationship. The value of the coefficient of determination or the contribution of the influence of $\mathrm{X}$ on $\mathrm{Y}$ by 0.454 . This shows that the achievement of variable $\mathrm{Y}$ (Work Readiness) can be explained by the variable X (Soft Skill) of $45.4 \%$. While $54.6 \%$ is determined by other variables not examined.
\end{abstract}

Keywords: Soft skill, Job readiness, Effect of Soft Skills.

\section{Introduction}

Schools and colleges are institutions that have the task of educating and producing quality human beings in terms of knowledge, attitudes and skills whose achievements are formed in a planned, directed and systematic manner. Learning activities or teaching and learning process are the main things in the education process. Therefore, the implementation of education is integral with the learning process that lead to the process of achieving learning objectives.

According to Law No.20 of 2003 article 19 paragraph 1: "What is meant by higher education is the level of education after secondary education includes diploma, undergraduate, master's, specialist and doctoral education programs organized by universities". This new era of 
civilization requires universities to be able to produce graduates to master the ability of the workforce to survive and develop to achieve the actualization of excellence optimally. The ability of the workforce is not only in the form of intellectual intelligence but also emotional and spiritual intelligence. Intellectual intelligence is related to hard skills in certain fields which are demonstrated through work readiness, while emotional and spiritual intelligence are related to soft skills abilities associated with personality characteristics.

Soft skill is an ability, talent, or skill that exists in every human being. Soft skills are abilities that are carried out in a non-technical way, meaning that they are formless or invisible. However, soft skills can be categorized as personal and interpersonal skills. The definition of personal soft skills is the ability that is used for self-interest. For example, being able to control emotions in themselves, be able to take advice from others, be able to manage time, and always think positively, it can all be categorized as personal soft skills. Then interpersonal soft skills are defined as the skills used for oneself and others. For example, we are able to relate or interact with other people, work together with other groups, and others.

As mentioned earlier, universities are required to educate graduates who can bring success in developing career paths or professional workforce. However, the current soft skills of the students are quite alarming. Many various opinions argue that the soft skills have not been fully mastered by university graduates. Therefore, many university graduates have not been employed in their respective field. Many of the students are less able to communicate verbally. Their honesty / integrity is quite worrisome, often cheating during exams or when working on assignments, impolite and unable to collaborate with their peers. In this study, the students of Civil Engineering study program were chosen because the study program has advantages in terms of hard skills in the courses they take. In addition, the employment does not only require hard skills but also soft skills.

\section{Method}

The research used descriptive verification method with ex post facto and survey research. Ex post facto consists of three words, ex means observation or observation, post means after, and facto is fact or event. The overall meaning of the Ex post facto research is that it reveals events that have occurred and looks at various factors associated 
with these events. Descriptive research is research intended to investigate the circumstances, conditions or other things that have been mentioned, the results of which are presented in the form of research reports, while verification research is research that aims to check the truth of other research results (Arikunto, 2013: 3).

\section{Research Results and Discussion}

Based on the description above, the purposes of this study are to find out:

\subsection{Soft Skill Level of the Students}

The results of study regarding how the ability of soft skills of the Civil Engineering students of the Universitas Negeri Semarang showed that their soft skills are included in the fair category. The average score of the $\mathrm{X}$ variable is 95.5 located with the range of values of $92.5<$ $\mathrm{X} \leq 99$ with the statement "fair".

\subsection{Level of Work Readiness}

The results of research conducted by researchers showed that the level of Work Readiness of students included in the category of "Fair". The average score of the Y variable is 102.73 which lies in the range of values of $94,26<X \leq 104,5$ with the category of "fair".

\subsection{Effect of Soft Skill on Work Readiness}

Based on the results of study conducted by researchers using the simple linear regression analysis, the regression equation $\mathrm{Y}=23.840+0.826 \mathrm{X}$ was obtained. The equation provides information that the consistency value of variable $\mathrm{Y}$ (Work Readiness) is 23,840. Regression coefficient X (Soft Skill) of 0.826 states that for each addition of $1 \%$ the value of soft skills, the value of work readiness increases by 0.826 . The regression coefficient is positive. Therefore, it can be said that the direction of the influence of the variable X (Soft Skill) on the variable Y (Work Readiness) is positive. There is a positive influence between soft skills on students' readiness in facing the employment in 2016 class of Civil Engineering study program at the Universitas Negeri Semarang. 


\section{Conclusions and suggestions}

Based on the results of the study, the following conclusions can be drawn:

1. Based on descriptive analysis in this study, the level of soft skills of Civil Engineering students of the Universitas Negeri Semarang is included in the category of Fair with an average value of 95.5 .

2. Based on the descriptive analysis in this study, the Work Readiness of Civil Engineering students of Universitas Negeri Semarang was included in the Fair category with an average value of 102.7

3. Based on the hypothesis test in this study, a significant effect was obtained between soft skills and students' readiness in facing the employment in the Civil Engineering study program at the Universitas Negeri Semarang. This was evidenced by:

a. The coefficient of determination $\left(\mathrm{R}^{2}\right)=0.454$ which means that it has $45.4 \%$ of the work readiness achievement (Y) to 40 students can be explained by the soft skills variable (X), but $54.6 \%$ were caused by other variables which are not explained in this study.

b. Significance test was obtained from $t_{\text {staisisics }}=5,617>t_{\text {critical }}=2,024$ with a significance value of $0,000<$ significance level $(0.05)$. In this case it has a regression line equation $Y=23,840+0,826 X$.

Based on the results of the study, these following suggestions can be given:

1. The students of Civil Engineering study program, Universitas Negeri Semarang are expected to improve their soft skills especially developing soft skills required for the employment.

2. Teachers must always motivate students and provide guidance for students to develop their soft skills. 


\section{References}

[1] Aprianti, D and M. Sugandi. 2015. Soft Skill Contribution to Work Readiness of Students in Technical Drawing Skills in Vocational High School Buildings. Jurnal Bangunan 20 (1): 25.

[2] Arikunto, Suharsini. 2013. Research Procedure: A Practical Approach. Fifteenth Edition. Jakarta: PT. Rineka Cipta.

[3] Elfindri, J. Rumengan, et al. 2010. Soft Skills for Educators: Baduose Media.

[4] Irawan, D. Aji and W. Suprapti. 2018. Soft Skill Revolution: Guiding Effective Learning with the $7 M$ Method. Mojokerto: CV. Sepilar Publishing House.

[5] Lie, N and Krishna. 2017. The Effect of Soft Skill on Work Readiness Facing the ASEAN Economic Community in S1 Students of the Faculty of Business and Economics, University of Surabaya. University of Surabaya Student Scientific Journal 6 (2): 1502-1504.

[6] Slameto 2010. Learning and Factors That Influence It. Fifth Edition. Jakarta: Rineka Cipta.

[7] Sugiyono 2014. Statistics for Research . Bandung: Alfabeta.

[8] 2016. Educational Research Methods: Quantitative, Qualitative, and R\&D Approaches . 23rd edition. Bandung: Alfabeta.

[9] Sutanto, Teguh. 2012. Soft Skill Success in the World of Work: How to Build a Career and Liked in the World of Work? . Yogyakarta: Smart Book.

[10] Law of the Republic of Indonesia Number 20 of 2003. National Education System . July 8, 2003. State Gazette of the Republic of Indonesia of 2003 Number 4301. Jakarta. 